\title{
Spontaneous recovery and the structure of plant community after agriculture use and fire in grasslands in the Vila Velha state park, South Brazil
}

\begin{abstract}
This study compares the plant structure of native and passive regenerated grassland areas in the Vila Velha State Park, southern Brazil. We analyzed four data set and observed that: (i) areas former submitted both to agricultural activity and fire showed lower species diversity (mainly Poaceae) and three abundant taxa (the ruderale grasses Eragrostis airoides, Andropogon bicornis, and Eustachys distichophylla); (ii) in grasslands former cultivated but not burned for the last 10 years, species diversity was slight higher and abundant taxa included the grasses Andropogon bicornis, Paspalum distichum, and Paspalum paspalodes, and the herbs Pteridium arachnoideum and Baccharis dracunculifolia; (iii) in native grasslands, never used for agriculture but recently burned, species diversity is higher but abundant taxa were just the grasses Aristida jubata and Paspalum rhodopedum; (iv) in native grasslands never cultivated nor burned for the last 10 years, species diversity was much higher and abundant taxa were the herbs Grazielia gaudichaudiana, Stevia clausenii, Chrysolaena platensis, and Lessingianthus grandiflorus. Additionally, typical grassland taxa as Chromolaena verbenacea, Allagoptera campestris, Croton antisiphyliticus, Cayaponia espelina, Leandra erostrata, and Byttneria hatschbachii have been found only in the undisturbed area. Thus, the areas showed diverse floristic composition, yet their biodiversity metrics and functional groups did not differ significantly. In summary, despite agriculture and fire decreasing the park species diversity, the base level for spontaneous recovery process did not reach thresholds that would prevent the maintenance of community structure.
\end{abstract}

Keywords: restoration, subtropical grasslands, abandoned arable land, fire disturbance, passive regeneration
Volume 2 Issue 2 - 2018

\author{
Rosemeri Segecin Moro,' Karine Dalazoana, ${ }^{2}$ \\ Tatyana Hohmann Novochadlo ${ }^{3}$ \\ 'Universidade Estadual de Ponta Grossa, Brazil \\ ${ }^{2}$ Centro de Ensino Superior dos Campos Gerais, Brazil \\ ${ }^{3}$ Secretaria Municipal de Saúde de Ponta Grossa, Brazil
}

Correspondence: Rosemeri Segecin Moro, Post graduation Program Geography Universidade Estadual de Ponta Grossa, Av. Carlos Cavalcanti, 4748, Ponta Grossa, Paraná, Brazil, Tel +55 42-3220-3I55,Email rsmoro@uepg.br

Received: February 20, 2018| Published: April 25, 2018
Abbreviations: VVSP, Vila Velha state park; SEMA/IAP, Brazilian environmental agency

\section{Introduction}

The subtropical grasslands in South Brazil known as Campos Gerais are the main vegetation in the highlands along the topographic slope called Escarpa Devoniana, in the State of Paraná. South American native grasslands probably evolved under a disturbing system of grazing and fire $^{1}$ that supposedly selected species since pre-historic ages ${ }^{2}$. Their plant composition and structure are well known $^{3-10}$ as well as their response to anthropogenic impacts such as grazing and touristic activities. ${ }^{11,12}$ Nevertheless, there are few data about spontaneous recovery in abandoned arable land and after fires. ${ }^{13-16}$

Fires could directly affect plant community structure in grasslands interfering with the growing, survival and reproduction of plants and their seed banks. ${ }^{16}$ The secondary vegetal succession starts when resilient species besides other dispersers recolonize the disturbed area. Generally, some few species more tolerant to the new environmental conditions will quickly dominate the space, mainly grasses. According to Baldissera et al. ${ }^{17}$ these dominant caespitous grasses suppresses many forbs, reducing the species richness and evenness. Moreover, disturbances limit the growing of dominants and allow the development of other forbs species. Ultimately, the effects of the conversion of grasslands to other land uses in subtropical grasslands are poorly understood.
Therefore, this study investigates the effect of agriculture and fire disturbance on a grassland plant community in the past 10 years, considering species composition, richness and evenness. This paper aims to contribute to the fire prescription discussion as well as to restoration programs. ${ }^{14,18}$ The main hypothesis is that after a period of spontaneous recovery disturbances lead to significant differences in floristic composition with no significant changes in the community structure.

\section{Materials and methods}

The Vila Velha State Park (VVSP), located in the Campos Gerais region, is a 1,000 meters high plateau at South Brazil $\left(25^{\circ} 12^{\prime} 34^{\prime \prime}\right.$, $25^{\circ} 15^{\prime} 35^{\prime \prime} \mathrm{S}$; 49 $\left.58^{\prime} 04^{\prime \prime}, 50^{\circ} 03^{\prime} 37^{\prime \prime} \mathrm{W}\right)$. Their 3,803.3 ha encloses the last significant grasslands remnants of the Atlantic Forest Biome under a subtropical climate (Cfb Koeppen). At the sampled site, the soils are mainly Latosols. ${ }^{19}$

We selected four sample areas as follows: (A) former grassland subjected to annual cropping (soy bean and corn) and frequent natural fires in the last 10 years; (B) former grassland subjected to cropping but free from burning in the last 10 years; (C) native grassland never cultivated but burned by natural fires; (D) native grassland never cultivated nor burned for the last 10 years (control area) (Figures 1) (Figure 2). For the phytosociological survey we employed for each area three $15 \mathrm{~m}$ transects sampled each $0.5 \mathrm{~m}$, summing 360 points. ${ }^{20}$ The vouchers are at the HUPG herbarium (in the Ponta Grossa State University). The taxonomic classification of flowering plants 
followed APG IV. ${ }^{21}$ Common and dominant species followed Lobo \& Leighton. ${ }^{22}$ Life forms followed Raunkiaer classification. ${ }^{23}$ Species richness, Shannon-Wiener diversity, Pielou evenness, and Sorensen similarity were computed for all areas. Frequency data were analyzed by ANOVA One-Way and Welch's test; comparisons between groups were based on Tukey's test; and means were compared by t-test.

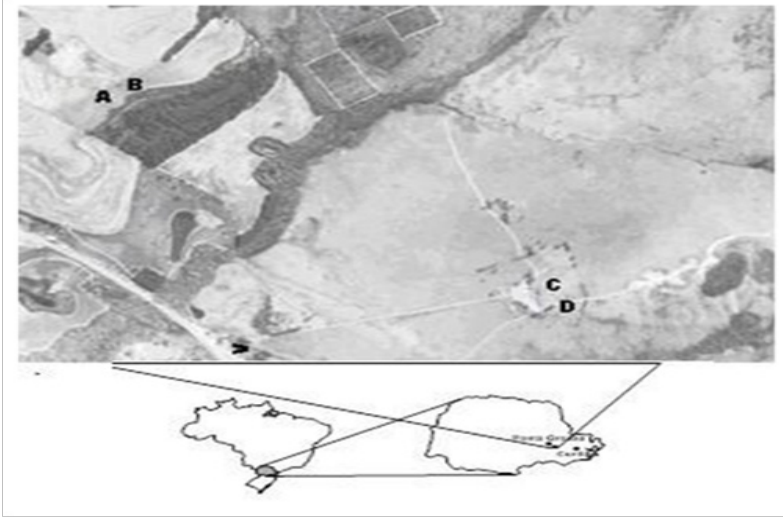

Figure 1 Studied sites at the Vila Velha State Park, Brazil: A, B, C, and D.
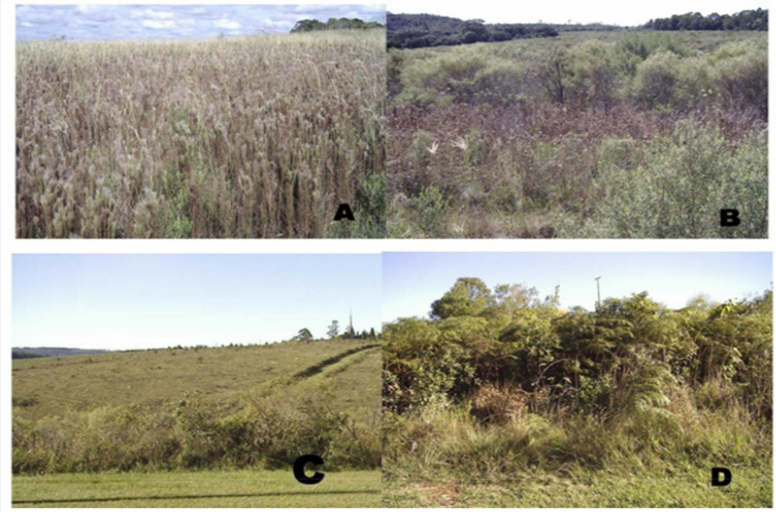

Figure 2 Vegetation aspect of the sample sites: (A) Cropped and burned. (B) Just cropped, not burned. (C) Just burned, not cropped. (D) Never cropped nor burned.

\section{Results and discussion}

We determined 510 individuals belonging to 57 taxa -18 flowering plants families and 1 fern (Table 1). The most representative families were Asteraceae (herbs) and Poaceae (grasses) that had already been pointed out in previous studies. ${ }^{6,10,13}$ Density and frequency analyses showed that the most prevalent species were grasses, mainly Andropogon bicornis and Aristida jubata, and the fern Pteridium arachnoideum. None of the areas showed dominant species. In the area A, with a historic of cultivation and fire events, diversity was the lowest $\left(\mathrm{H}^{\prime}=1.76\right)$, presenting mainly grasses (Eragrostis airoides, Andropogon bicornis, and Eustachys distichophylla). In the area B, formerly cultivated with soy bean/corn but not burned for the last 10 years, diversity was slight higher $\left(\mathrm{H}^{\prime}=1.85\right)$ and abundant taxa encompassed grasses (Andropogon bicornis, Paspalum distichum, Paspalum paspalodes), a fern (Pteridium arachnoideum), and herbs (Baccharis dracunculifolia). In the area $\mathrm{C}$, without a history of cultivation but recently burned, the diversity was even higher $\left(\mathrm{H}^{\prime}=2.06\right)$ but abundant taxa were just grasses (Aristida jubata, Paspalum rhodopedum). At last, in the area $\mathrm{D}$, never managed by agriculture nor burned for the last 10 years, diversity was the highest $\left(\mathrm{H}^{\prime}=2.65\right)$, and abundant taxa were all herbs (Grazielia gaudichaudiana, Stevia clausenii, Chrysolaena platensis, Lessingianthus grandiflorus).

It is worth pointing out that only in $\mathrm{C}$ and $\mathrm{D}$ occurred typical grassland taxa as Grazielia gaudichaudiana, Chromolaena verbenacea, Allagoptera campestris, Croton antisiphyliticus, Cayaponia espelina, Stevia clausenii, Chrysolaena platensis, Lessingianthus grandiflorus, Vernonanthura phosphorica, Leandra erostrata, and Byttneria hatschbachii. For Aximoff et al., ${ }^{24}$ structure, plant composition and species richness have recovered relatively fast (between 4 and 7 years) at the Itatiaia National Park, despite of the re-establishment (nevertheless, endemic and endangered species were not found after fire). In the same way, according to Andrade et al., ${ }^{25}$ the specificity of niche could interfere restoration after a great soil disturbance like cultivation, due to abiotic changes such as disturbances in soil chemicals and physical properties. If a self-recovery threshold is not crossed, the abandonment of this land use initiates re-colonization from the regional species pool. It is the persistent fraction of the seed bank in the soil that could determine the potential for reestablishment of original species and thus the resilience of degraded vegetation. ${ }^{25}$

According to Goudarzian \& Erfanifard, ${ }^{26}$ the species richness alone would not be used to estimate the species diversity. The species richness is biased toward rare species while the species evenness is biased toward dominant species, so they recommend applying a combination of richness, evenness and biodiversity to investigate the species diversity, as Table 2 reports. However, in this study we could not find significant differences among means of species richness and species evenness ( $>00.05$ ), although fire seems to lead to a more aggregate species distribution as indicated by the slightly lower evenness regarding unburned areas. There was a high linear co variation between richness and biodiversity $(\mathrm{r}=0.98)$ and the Principal Component Analysis showed that just one component was responsible for $0.98 \%$ of data variation. Species number, diversity and evenness did not differ among areas $(\mathrm{p}>0.8)$, as opposed to previous studies that have found three times lower richness in disturbed grassland due to wood species removal by fire. ${ }^{13}$ Nevertheless, authors wonder whether richness could be restored to a previous level after continuing succession towards the climax. ${ }^{16}$

The proportion of life forms does not also differ among the areas $(\mathrm{p}>0.27)$, where the most frequent were identified as chamephytes, cryptophytes, and hemicryptophytes. Miodusky \& Moro $^{7}$ have already identified that chamephytes, cryptophytes and hemicryptophytes form $96 \%$ of the species in native grassland outside VVSP. The high frequency of hemicryptophytes, that presents gems and bulbs protected on the soil level by scales, leaves or sheaves, were related both to fires as to the diurnal thermic variation and well-marked seasonality, besides cold winds and frosts. ${ }^{24}$ The high prevalence of cryptophytes is significant as well. Many forbs and small shrubs depend on re-sprouting from underground storage organs after biomass loss, which may indicate that the seed bank is of little relevance for typical grassland vegetation recovery after this kind of disturbance. ${ }^{27}$ Relating to the height average of individuals, no burned areas tend to develop higher vegetation. Abandoned arable land could show a very vigorous growing, but the differences were not significant ( $p>0.88$ ).

Sorensen similarities among the four areas were very low. As Sorensen index considers just categorical data based on presence/ absence of species, we performed a cluster analysis upon the species frequency to highlight similar groups upon the variances of the species 
frequencies. Cluster analyses have reassured the related groups by clustering the same A, B, C, and D areas (Figure 3). There is one cluster related to the sampled area $\mathrm{A}$, which suggests that agriculture is a species selecting factor more significant than fire. The next cluster included transects of area C (burned). Areas B and D, both unburned, has been joined in a third cluster.

Table 1 Taxa in the studied areas A, B, C, and D, in the Vila Velha State Park, Brazil

\begin{tabular}{|c|c|c|c|c|c|c|}
\hline Family & Taxa & Area & $\mathbf{L F}$ & RF\% & Habit & $\mathbf{H}$ \\
\hline Apiaceae & Eryngium junceum Cham. \& Schl. & $\mathrm{C} ; \mathrm{D}$ & $\mathrm{Hm}$ & 1.4 & $\mathrm{Hb}$ & 58 \\
\hline \multirow[t]{11}{*}{ Arecaceae } & Allagoptera campestris Mart. Krentze & $\mathrm{C} ; \mathrm{D}$ & $\mathrm{Cr}$ & 0.6 & Sch & 100 \\
\hline & Achyrocline satureioides (Lam.) DC. & $\mathrm{C} ; \mathrm{D}$ & $\mathrm{Ch}$ & 0.4 & $\mathrm{Hb}$ & 80 \\
\hline & Aster squamatus (Spreng.) Hieron. & $\mathrm{B}$ & Ter & 0.2 & $\mathrm{Hb}$ & 110 \\
\hline & Baccharis dracunculifolia DC. & $\begin{array}{l}\text { A; B; } \\
\text { C; D }\end{array}$ & $\mathrm{Ch}$ & 6.7 & Sch & 102 \\
\hline & Baccharis trimera (Less) DC. & $\mathrm{C} ; \mathrm{D}$ & $\mathrm{Cr}$ & 0.8 & $\mathrm{Hb}$ & 35 \\
\hline & Baccharis sp & $\mathrm{A} ; \mathrm{B}$ & - & 2.2 & Sch & 35 \\
\hline & $\begin{array}{l}\text { Chromolaena laevigata (Lam.) R.M. } \\
\text { King \& H. Rob. }\end{array}$ & $\mathrm{C}$ & $\mathrm{Cr}$ & 0.2 & $\mathrm{Hb}$ & 130 \\
\hline & $\begin{array}{l}\text { Chromolaena verbenacea (DC.) R.M. } \\
\text { King \& H. Rob. }\end{array}$ & $\mathrm{D}$ & $\mathrm{Ch}$ & 0.2 & $\mathrm{Hb}$ & 150 \\
\hline & Chrysolaena platensis (Spreng.) H. Rob. & $\mathrm{C}$ & $\mathrm{Ch}$ & 0.2 & $\mathrm{Hb}$ & 80 \\
\hline & $\begin{array}{l}\text { Eupatorium tanacetifolium Gillies ex } \\
\text { Hook. \& Arn }\end{array}$ & $\mathrm{B}$ & $\mathrm{Hm}$ & 0.4 & $\mathrm{Hb}$ & 30 \\
\hline & $\begin{array}{l}\text { Gochnatia argyrea (Dusén ex Malme) } \\
\text { Cabrera }\end{array}$ & $\mathrm{D}$ & $\mathrm{Ch}$ & 1.2 & $\mathrm{Hb}$ & 70 \\
\hline \multirow{10}{*}{ Asteraceae } & $\begin{array}{l}\text { Grazielia gaudichaudiana (DC.) R.M. } \\
\text { King \& H. Rob. }\end{array}$ & $\mathrm{C} ; \mathrm{D}$ & $\mathrm{Ph}$ & 0.4 & $\mathrm{Hb}$ & 130 \\
\hline & $\begin{array}{l}\text { Heterocondylus alatus (Vell.) R.M. King } \\
\text { \& H. Rob. }\end{array}$ & $\mathrm{A}$ & $\mathrm{Ch}$ & 0.4 & $\mathrm{Hb}$ & 200 \\
\hline & $\begin{array}{l}\text { Lessingianthus macrocephalus (Less.) } \\
\text { H. Rob. }\end{array}$ & $\mathrm{C}$ & $\mathrm{Ch}$ & 0.2 & $\mathrm{Hb}$ & 80 \\
\hline & $\begin{array}{l}\text { Lessingianthus grandiflorus (Less.) H. } \\
\text { Rob. }\end{array}$ & $\mathrm{D}$ & $\mathrm{Cr}$ & 0.2 & $\mathrm{Hb}$ & 80 \\
\hline & Mikania micrantha Kunth & $\mathrm{B}$ & Lia & 0.2 & $\mathrm{Sc}$ & 15 \\
\hline & Senecio brasiliensis (Spreng.) Less & $\mathrm{B}$ & Ter & 0.4 & $\mathrm{Hb}$ & 195 \\
\hline & Stevia clauseni Schultz-Bip ex Baker & $\mathrm{D}$ & $\mathrm{Ch}$ & 0.2 & $\mathrm{Hb}$ & 60 \\
\hline & $\begin{array}{l}\text { Stenochepalum megapotamicum } \\
\text { (Spreng.) Sch.Bip. }\end{array}$ & A & $\mathrm{Ch}$ & 0.2 & $\mathrm{Hb}$ & 20 \\
\hline & $\begin{array}{l}\text { Vernonanthura phosphorica (Vell.) H. } \\
\text { Rob. }\end{array}$ & $\mathrm{D}$ & $\mathrm{Ch}$ & 0.2 & $\mathrm{Hb}$ & 30 \\
\hline & Asteraceae 1 & $\mathrm{C}$ & - & 0.4 & $\mathrm{Hb}$ & 50 \\
\hline Bignoniaceae & Jacaranda caroba (Vel.) DC. & $\mathrm{C} ; \mathrm{D}$ & $\mathrm{Ch}$ & 0.8 & Sch & 65 \\
\hline Campanuleaceae & Wahlenbergia linarioides (Lam.) A. DC. & $\mathrm{A}$ & $\mathrm{Ch}$ & 0.6 & $\mathrm{Hb}$ & 40 \\
\hline Convolvulaceae & Ipomoea ramosissima (Poer.) Choisy & $\mathrm{D}$ & Lia & 2.2 & $\mathrm{Sc}$ & 150 \\
\hline Cucurbitaceae & Cayaponia espelina (Manso) Cogn. & $\mathrm{D}$ & Lia & 0.2 & $\mathrm{Sc}$ & 60 \\
\hline \multirow{2}{*}{ Cyperaceae } & $\begin{array}{l}\text { Bulbostylis capillaris (L.) Kunth ex } \\
\text { C.B.Clarke }\end{array}$ & $\mathrm{D}$ & $\mathrm{Hm}$ & 0.2 & $\mathrm{Hb}$ & 20 \\
\hline & Kyllinga brevifolia Rottb. & $\mathrm{D}$ & $\mathrm{Hm}$ & 0.2 & $\mathrm{Hb}$ & 15 \\
\hline Dennstaedtiaceae & $\begin{array}{l}\text { Pteridium arachnoideum (Kaulf.) } \\
\text { Maxon. }\end{array}$ & $\mathrm{A} ; \mathrm{B} ; \mathrm{D}$ & $\mathrm{Cr}$ & 11.8 & $\mathrm{Hb}$ & 56 \\
\hline Euphorbiaceae & Croton antisyphiliticus Mart. & $\mathrm{C}$ & $\mathrm{Ch}$ & 0.2 & $\mathrm{Hb}$ & 30 \\
\hline
\end{tabular}


Table Continued

\begin{tabular}{|c|c|c|c|c|c|c|}
\hline Family & Taxa & Area & $\mathbf{L F}$ & RF\% & Habit & $\mathbf{H}$ \\
\hline & Desmodium tortuosum (Sw.) DC. & A & $\mathrm{Ch}$ & 0.4 & $\mathrm{Sc}$ & 120 \\
\hline \multirow[t]{2}{*}{ Fabaceae } & Mimosa dolens (Benth) Barneby & $\mathrm{C}$ & $\mathrm{Ch}$ & 0.4 & Sch & 60 \\
\hline & Rhynchosia corylifolia Benth. & $\mathrm{C}$ & Lia & 0.2 & $\mathrm{Hb}$ & 60 \\
\hline Hypericaceae & Hypericum cordatum (Vell.) N. Robson & $\mathrm{D}$ & $\mathrm{Ch}$ & 0.2 & $\mathrm{Hb}$ & 20 \\
\hline Iridaceae & Sisyrinchium vaginatum Spreng. & $\mathrm{C}$ & $\mathrm{Cr}$ & 0.6 & $\mathrm{Hb}$ & 50 \\
\hline Malvaceae & Byttneria hatschbachii Crist. & $\mathrm{C}$ & $\mathrm{Ch}$ & 0.2 & $\mathrm{Sc}$ & 50 \\
\hline \multirow[t]{9}{*}{ Melastomataceae } & Leandra erostrata (DC.) Cogn. & $\mathrm{D}$ & $\mathrm{Ch}$ & 0.2 & $\mathrm{Hb}$ & 90 \\
\hline & Tibouchina debilis (Cham.) Cogn. & $\mathrm{D}$ & $\mathrm{Ch}$ & 0.2 & $\mathrm{Hb}$ & 30 \\
\hline & Andropogon bicornis $\mathrm{L}$. & A; B ; D & $\mathrm{Cr}$ & 15.4 & $\mathrm{Hb}$ & 115 \\
\hline & Andropogon ternatus (Spreng.) Nees & $\mathrm{C} ; \mathrm{D}$ & Ter & 0.8 & $\mathrm{Hb}$ & 65 \\
\hline & Aristida jubata (Arechav) Herter & $\mathrm{C} ; \mathrm{D}$ & $\mathrm{Hm}$ & 12.2 & $\mathrm{Hb}$ & 50 \\
\hline & Eragrostis airoides Ness & A & $\mathrm{Hm}$ & 10.6 & $\mathrm{Hb}$ & 20 \\
\hline & Eragrostis sp & A & $\mathrm{Hm}$ & 0.2 & $\mathrm{Hb}$ & 100 \\
\hline & Eustachys distichophylla (Lag.) Nees & $\mathrm{A} ; \mathrm{B}$ & $\mathrm{Hm}$ & 7.7 & $\mathrm{Hb}$ & 120 \\
\hline & Imperata brasiliensis Trinius & $\mathrm{D}$ & $\mathrm{Hm}$ & 2.4 & $\mathrm{Hb}$ & 200 \\
\hline \multirow[t]{8}{*}{ Poaceae } & Panicum millegrana Poir. & $\mathrm{D}$ & $\mathrm{Cr}$ & 0.2 & $\mathrm{Hb}$ & 80 \\
\hline & Panicum sabulorum Lam. & $\mathrm{D}$ & $\mathrm{Hm}$ & 0.8 & $\mathrm{Hb}$ & 90 \\
\hline & Paspalum distichum L. Gram. & B & $\mathrm{Hm}$ & 4.9 & $\mathrm{Hb}$ & 33 \\
\hline & Paspalum erianthum Nees ex Trin. & $\mathrm{C} ; \mathrm{D}$ & $\mathrm{Hm}$ & 2.4 & $\mathrm{Hb}$ & 50 \\
\hline & Paspalum guenoarum Arechav. & $\mathrm{C}$ & $\mathrm{Cr}$ & 3.5 & $\mathrm{Hb}$ & 60 \\
\hline & Paspalum maritimum Trinius & A & $\mathrm{Hm}$ & 0.2 & $\mathrm{Hb}$ & 40 \\
\hline & Paspalum sp & A & - & 0.2 & $\mathrm{Hb}$ & 50 \\
\hline & $\begin{array}{l}\text { Pseudechinolaena polystachya (HBK) } \\
\text { Stapf }\end{array}$ & $\mathrm{D}$ & $\mathrm{Ch}$ & 0.2 & $\mathrm{Hb}$ & 20 \\
\hline Rhamnaceae & $\begin{array}{l}\text { Frangula sphaerosperma (Sw.) Kartesz } \\
\& \text { Gandhi }\end{array}$ & $\mathrm{D}$ & $\mathrm{Ph}$ & 0.8 & Sch & 150 \\
\hline Scrophulariaceae & Buddleja elegans Cham. \& Schl. & B & $\mathrm{Ph}$ & 0.4 & $\mathrm{Hb}$ & 50 \\
\hline Verbenaceae & Lantana camara $\mathrm{L}$. & $\mathrm{D}$ & $\mathrm{Ph}$ & 0.2 & Sch & 150 \\
\hline Unknown & & $\mathrm{D}$ & - & 0.2 & $\mathrm{Hb}$ & 100 \\
\hline
\end{tabular}

LF, life form; Ch, chamephyte; Hm, hemicryptophyte; Cr, cryptophyte; Ter, terophyte; Lia, liana/scandent; Ph, phanerophyte; RF, relative frequency; Hb, herbs; Sch, shrubs; Sc, scandent; $\mathrm{H}$, average height in $\mathrm{cm}$ 
Table 2 Plant community structure descriptors in the sampled areas of the Vila Velha State Park, Brazil

\begin{tabular}{|c|c|c|c|c|c|c|}
\hline Area & $\mathbf{S}$ & $\mathbf{H}^{\prime}$ & $\mathbf{E}$ & $\mathbf{h}$ & So & $\%$ \\
\hline & & & & & $A, B=0.40$ & Ch 41.6 \\
\hline \multirow[t]{3}{*}{ A } & 13 & 1.76 & 0.69 & 78.3 & $A, C=0.06$ & $\mathrm{Cr} 16.7$ \\
\hline & & & & & $A, D=0.14$ & $\mathrm{Hm} 33.3$ \\
\hline & & & & & $\mathrm{B}, \mathrm{A}=0.40$ & Ch 10.0 \\
\hline \multirow[t]{3}{*}{ B } & 11 & 1.85 & 0.77 & 74.3 & $B, C=0.06$ & Cr 20.0 \\
\hline & & & & & $B, D=0.14$ & $\mathrm{Hm} 30.0$ \\
\hline & & & & & $C, A=0.06$ & Ch 44.4 \\
\hline \multirow[t]{3}{*}{ C } & 20 & 2.06 & 0.69 & 69.3 & $C, B=0.06$ & Cr 27.8 \\
\hline & & & & & $C, D=0.39$ & $\mathrm{Hm} 16.7$ \\
\hline & & & & & $\mathrm{D}, \mathrm{A}=0.14$ & Ch 40.0 \\
\hline \multirow[t]{2}{*}{ D } & 32 & 2.65 & 0.76 & 79.7 & $D, B=0.14$ & Cr 20.0 \\
\hline & & & & & $D, C=0.39$ & $\mathrm{Hm} 20.0$ \\
\hline
\end{tabular}

S, species richness; H', shannon diversity; E, pielou evenness; h, mean high; So, sorensen similarity; $\mathrm{Ch}$, frequency of chamephytes; $\mathrm{Cr}$, cryptophytes; $\mathrm{Hm}$, hemicryptophytes

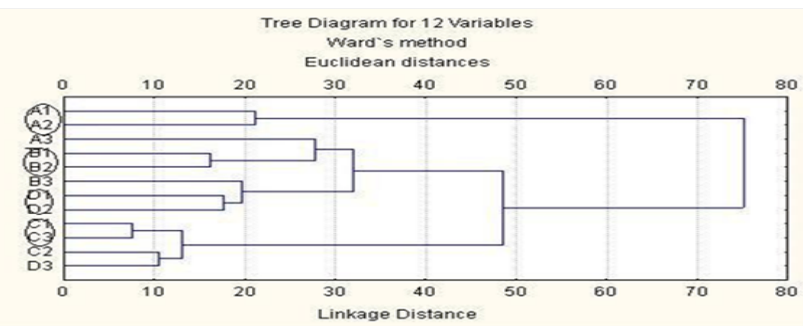

Figure 3 Cluster analysis of 57 taxa frequency along 12 transects in the sampled areas $A, B, C$, and $D$.

The biodiversity is related to the resilience and stability of an ecosystem ${ }^{28}$ and, according to Koch et al., ${ }^{29}$ all land use forms bring deviations from original grasslands. We estimated that the initial decrease in the number of species in the burned areas were been reversed along the time, ${ }^{30}$ whereas the strong compositional changes induced by agriculture use may require the re-introduction of grassland species in an active restoration process.

\section{Conclusion}

The selected areas have diverse floristic composition yet maintaining a similar plant structure in terms of biodiversity and functional groups. Agriculture and fire decreased the specific diversity and the base level for spontaneous recovery process. However, in VVSP these disturbances probably could not reach a threshold that would make spontaneous recovery unfeasible.

In areas with a history of cultivation due to the removal of underground organs there is no persistence of the typical cryptophytic species usually found in natural subtropical grasslands. Restoration by means of spontaneous recovery of these altered areas to nearnatural grassland may require additional technical measures to reintroduce these species. There were exclusive species in unburned areas that indicate the fire importance in selecting organisms within the communities. In the sampled areas, fire strongly selected ruderal species as Andropogon bicornis, Baccharis spp, Senecio brasiliensis, and Aster squamatus, among others. Even so, many hemicryptophytes were favored by the fires and apparently have been retake their original abundance. The native burned studied areas presented a grassy character contrasting the unburned wood area.

Perhaps avoiding fires at all will not be a good strategy for grassland conservation, considering that ecosystems are not static and the natural species succession in southern Brazil is strongly in curse towards forest type vegetation as result of regional and global climate changes. It would not be sensible, therefore, to expect that the vegetation of protected areas could be sustained indefinitely. Nevertheless, one could try to retain the original characteristics of grasslands by means of controlled fire.

\section{Acknowledgements}

To SEMA/IAP and EcoParaná for supporting the research at the VVSP, mainly to Luiz Augusto Diedrichs (IAP); to Dr. Cristina G. de Almeida for participating on the field and herbarium work; to Dr. Lucas Antiqueira for the language review.

\section{Conflict of interest}

Authors declare there is no conflict of interest in publishing the article.

\section{References}

1. Pillar V de P, Quadros FLP. Grassland-forest boundaries in southern Brazil. Coenoses. 1997;12(2-3):119-126.

2. Behling H. Late Quaternary vegetation, climate and fire history in the Araucaria forest and campos region from Serra Campos Gerais (Paraná), South Brazil. Rev Paleobot Palynol. 1997;97(1-2):109-121.

3. Klein RM, Hatschbach G. Fitofisionomia e notas complementares sobre o mapa fitogeográfico de Quero-Quero (Paraná). Bol Paran Geoc. 1970;28:159-188.

4. Hatschbach G, Moreira Filho H. Catálogo florístico do Parque Estadual de Vila Velha (Estado do Paraná-Brasil). Bol Univ Fed Paraná. 1972;28:1-54.

5. Cervi AC, von Linsingen $\mathrm{L}$, Hatschbach $\mathrm{G}$, et al. A vegetação do Parque Estadual de Vila Velha, município de Ponta Grossa, Paraná, Brasil. Bol Mus Bot Mun. 2007;69:1-52.

6. Dalazoana K, Silva MA, Moro RS. Comparação de três fisionomias de campo natural do Parque Estadual de Vila Velha, Ponta Grossa, PR. Rev Bras Bioc. 2007;5(1):675-577.

7. Mioduski J, Moro RS. Grupos funcionais da vegetação campestre de Alagados, Ponta Grossa, Paraná. Iheringia ser Bot. 2011;66(2):241-256.

8. Moro RS, Souza-Nogueira MKF de, Milan E, et al. Grassland Vegetation of Pitangui River Valley, Southern Brazil. Int J Ecosyst. 2012;2(6):161-170.

9. Kozera C, Kuniyoshi YS, Galvão F, et al. Espécies vasculares de uma área de campos naturais do sul do Brasil em diferentes unidades pedológicas e regimes hídricos. Rev Bras Bioc. 2012;10(3):267-274.

10. Ribeiro da Silva A, Andrade ALP, Velazco ES, et al. Floristic and phytosociology of three different grassland physiognomies of Southern Brazil. Hoehnea. 2016;43(3):325-347.

11. Dalazoana K, Moro RS. Riqueza específica em áreas de campo nativo impactadas por visitação turística e pastejo no Parque Nacional dos 
Campos Gerais, PR. Revista Floresta. 2011;41(2):387-396.

12. Andrade BO, Kozera C, Curcio GR, et al. Vascular grassland plants of Tibagi River Spring, Ponta Grossa, Brazil. Check List J. 2011;7(3):257-262.

13. Oliveira MB, Maranho LT. Efeitos do fogo controlado e do roçado sobre a sucessão ecológica da Estepe Gramíneo-Lenhosa no Parque Estadual de Vila Velha, PR, Brasil, em área com avanço de vassoura (Bacharis spp.). In: Carpanezzi OTB, Campos JB, editors. Coletânea de pesquisas: Parques Estaduais de Vila Velha, Cerrado e Guartelá. IAP, Curitiba, Brazil; 2011. p. 46-55.

14. Overbeck GE, Hermann JM, Andrade BO, et al. Restoration Ecology in Brazil - Time to Step Out of the Forest. Nat \& Cons. 2013;11(1):92-95.

15. Andrade AL, Moro RS, Kuniyoshi YS, et al. Floristic survey of the Furnas Gêmeas region, Campos Gerais National Park, Paraná state, southern Brazil. Check List J. 2017;13(6):879-899.

16. Heringer I, Jacques AVA. Adaptação das plantas ao fogo: enfoque na transição floresta- campo. Rev Ciên Rur. 2001;31(6):1085-1090.

17. Baldissera R, Fritz L, Rauber R, et al. Comparison between grassland communities with and without disturbances. Neotr Biol \& Cons. 2010;5(1):3-9.

18. Overbeck GE, Scasta JD, Furquim FF, et al. The South Brazilian grasslands - A South American tallgrass prairie? Parallels and implications of fire dependency. Persp Ecol Cons. 2018;16(1):24 30

19. IAP. Plano de Manejo do Parque Estadual de Vila Velha. Instituto Ambiental do Paraná, Curitiba, Brazil; 2004. 304 p.

20. Mantovani W, Martins FR. O método de pontos. Acta bot bras. 1990;4(2):95-121.

21. The Angiosperm Phylogeny Group, Chase MW, Christenhusz MJM, et al. An update of the Angiosperm Phylogeny Group classification for the orders and families of flowering plants: APG IV. Bot J Linn Soc. 2016;181(1):1-20.

22. Lobo E, Leighton G. Estructuras comunitarias de las fitocenosis planctónicas de los sistemas de desembocaduras de rios y esteros de la zona central del Chile. Rev Biol Mar. 1986;22(1):1-29.

23. Raunkiaer C (1934) The life forms of plants and statistical plant geography. Clarendon Press, Oxford, England; 104 p.

24. Aximoff I, Nunes-Freitas AF, Braga JMA. Post-fire natural regeneration of high altitude grasslands in the itatiaia national park, southeast of Brazil. Oecol Austr. 2016;20(2):62-80.

25. Andrade BO, Koch C, Boldrini II, et al. Grassland degradation and restoration: a conceptual framework of stages and thresholds illustrated by southern Brazilian grasslands. Nat \& Cons. 2015;13(2):95-104

26. Goudarzian P, Erfanifard SY. The Efficiency of Indices of Richness, Evenness and Biodiversity in the Investigation of Species Diversity Changes (Case Study: Migratory Water Birds of Parishan Internationa Wetland, Fars Province, Iran). Biodiversity Int J. 2017;1(2):41-45.

27. Vieira $\mathrm{M}$ de $\mathrm{S}$, Bonilha CL, Boldrini II, et al. The seed bank of subtropical grasslands with contrasting land-use history in southern Brazil. Acta bot bras. 2015;29(4):543-552.

28. Barkhas J. The Biodiversity Value. Biodiversity Int J. 2017;1(4):169-170

29. Koch C, Conradi T, Gossner MM, et al. Management intensity and temporary conversion to other land-use types affect plant diversity and species composition of subtropical grasslands in southern Brazil. J Appl Veg Sci. 2016;19(4):589-599.

30. Overbeck GE, Muller SC, Pillar V de P, et al. Composição florística, variação ambiental e distribuição das espécies em um campo queimado no sul do Brasil. Braz J Biol. 2006;66(4):1073-1090. 